\title{
PENGARUH LEVERAGE, FIRM SIZE, PROFITABIIITAS TERHADAP KEPUTUSAN HEDGING PADA PERUSAHAAN MANUFAKTUR DI BURSA EFEK INDONESIA
}

\author{
Ayuningtyas Putri Saraswati ${ }^{1}$ \\ Ni Putu Santi Suryantini ${ }^{2}$ \\ ${ }^{1,2}$ Fakultas Ekonomi dan Bisnis Universitas Udayana, Bali, Indonesia \\ email: ayuningtyasputris@yahoo.co.id
}

\begin{abstract}
ABSTRAK
Perdagangan internasional yang dilakukan oleh perusahaan multinasional dapat menimbulkan risiko yang akan ditanggung perusahaan. Risiko fluktuasi kurs valuta asing merupakan risiko terbesar yang mempengaruhi kegiatan perdagangan internasional sehingga untuk mengurangi dampak dari risiko tersebut perusahaan melakukan manajemen risiko dengan menggunakan kebijakan hedging. Penelitian ini bertujuan untuk menjelaskan pengaruh leverage, firm size, dan profitabilitas terhadap keputusan hedging pada perusahaan manufaktur di bursa efek Indonesia pada periode 2013-2017. Pengambilan sampel pada penelitian ini menggunakan teknik purposive sampling dan mendapat sampel sebanyak 107 perusahaan dan 535 firm year observation. Teknik analisis yang digunakan dalam penelitian ini menggunakan regresi logistik. Hasil penelitian menunjukkan bahwa debt to equity ratio sebagai proksi dari leverage memiliki pengaruh positif signifikan terhadap keputusan hedging, Ln(total asset) sebagai proksi dari firm size memiliki pengaruh positif signifikan terhadap keputusan hedging dan return on asset sebagai proksi dari profitabilitas memiliki pengaruh positif signifikan terhadap keputsan hedging.
\end{abstract}

Kata kunci: leverage, firm size, profitabilitas, hedging.

\begin{abstract}
International trade by multinational company can result in risk borne by the company. Foreign exchange rate fluctuation risk is the biggest rist that affect international trading activity. Therefore to reduce that risk, the company using hedging policy as risk management. This study is aimed to analyse the impact of leverage, firm size, and profitability of the hedging decision using derivative instruments in manufacturing companies listed in Indonesia Stock Exchange in 2013 until 2017. Sampling using purposive sampling techniques and according to the criteria established company obstained 107 sample and 535 dirm year observation. Logistic regression techniques was used to test this research. The result of this study indicates that variables debt to equity ratio as a proxy for leverage has a positive and significant effect on hedging activites, variables Ln(total asset) as a proxy for firn size has a positive and significant effect on hedging activities, and return on asset as proxy for profitability has a posistive and significant on hedging activities.
\end{abstract}

Key Word: leverage, firm size, profitability, hedging. 
Ayuningtyas Putri Saraswati dan Ni Putu Santi Suryantini, Pengaruh Leverage, Firm..

\section{PENDAHULUAN}

Perdagangan internasional merupakan salah satu cara yang dapat digunakan perusahaan dalam melakukan ekspansi pasar (Fitri, 2015). Perdagangan internasional merupakan suatu aktivitas transaksi jual beli yang dilakukan antar negara atau dengan pihak luar (Dewi, 2018). Perdagangan internasional tidak hanya membawa dampak positif bagi suatu perusahaan dalam hal peningkatan arus kas perusahaan, perdagangan internasional juga berdampak positif bagi suatu negara dari kegiatan ekspor dan impor yang dilakukan seperti kenaikan pendapatan domestik bruto, kenaikan devisa dan kesempatan kerja yang semakin luas. Hal ini dapat dilihat pada Tabel 1.

Tabel 1.

Nilai PDB pada Beberapa Sektor Usaha Atas Dasar Harga Konstan (Milliar Rp) Tahun 2013 - 2017

\begin{tabular}{|c|c|c|c|c|c|c|}
\hline \multirow[t]{2}{*}{ No } & \multirow[t]{2}{*}{ PDB } & \multicolumn{5}{|c|}{ Tahun } \\
\hline & & 2013 & 2014 & 2015 & 2016 & 2017 \\
\hline 1 & $\begin{array}{l}\text { Industri } \\
\text { Manufaktur }\end{array}$ & $1.774 .097,3$ & $1.637 .505,9$ & $1.720 .221,2$ & $1.796 .292,5$ & $1.906 .075,8$ \\
\hline 2 & $\begin{array}{l}\text { Perdagangan } \\
\text { Besar dan } \\
\text { Eceran; } \\
\text { Reparasi } \\
\text { Mobil dan } \\
\text { Motor }\end{array}$ & $1.118 .207,0$ & $1.117,048,6$ & $1.207 .751,1$ & $1.255 .224,9$ & $981.944,5$ \\
\hline 3 & $\begin{array}{l}\text { Pertanian, } \\
\text { Kehutanan } \\
\text { dan } \\
\text { Perikanan }\end{array}$ & $1.083 .141,8$ & 1.128 .448 & $1.171 .578,7$ & $1.209 .687,2$ & $1.085 .226,5$ \\
\hline
\end{tabular}

Sumber : www.bps.go.id,_2017

Pergerakan PDB pada Tabel 1. dapat dilihat bahwa industri manufaktur memiliki nilai PDB yang berfluktuasi setiap tahunnya dibandingkan dengan sektor lainnya. Meskipun nilai dari kedua sektor tersebut juga mengalami fluktuasi setiap tahunnya, namun peningkatan nilai dari masing - masing sektor tersebut belum dapat melebihi nilai yang diperoleh dari industri manufaktur. 
Berdasarkan hal tersebut dapat diperkirakan bahwa struktur perekonomian Indonesia hingga pada tahun 2017 masih dipengaruhi oleh industri manufaktur yang tetap menjadi the leading sector terhadap peningkatan PDB Nasional. Meskipun perusahaan manufaktur menjadi the leading sector terhadap PDB nasional, perusahaan manufaktur juga tetap memiliki kecenderungan terkena risiko dari kegiatan perdagangan internasional.

Krisdian (2017) menyatakan bahwa risiko terbesar dari transaksi internasional adalah risiko fluktuasi kurs valuta asing. Perubahan yang terjadi pada nilai mata uang asing yang tidak dapat diantisipasi dapat berdampak pada harga, laba eksportir dan importir serta tingkat penjualan perusahaan (Bartram, 2008). Perubahan nilai mata uang asing yang diakibatkan oleh fluktuasi kurs valuta asing dapat dilihat pada Gambar 1.

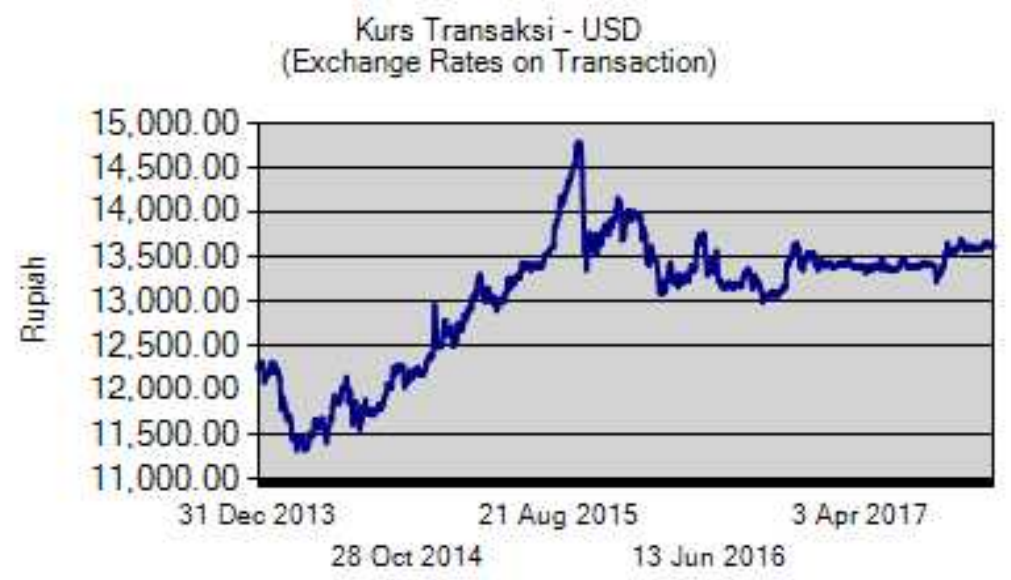

\section{Gambar 1. Kurs Valuta Asing Dolar Amerika}

Gambar 1 menunjukkan terjadinya fluktuasi kurs USD terhadap IDR dari tahun 2013 hingga 2017. Grafik kurs transaksi USD di atas menunjukkan kurs transaksi USD terhadap IDR selama 5 tahun yaitu mulai tanggal 31 Desember 
Ayuningtyas Putri Saraswati dan Ni Putu Santi Suryantini, Pengaruh Leverage, Firm..

2013 hingga 3 April 2017. Gambar di atas menunjukkan bahwa pada tanggal 31 Desember 2013 kurs transaksi USD terhadap IDR yaitu sebesar Rp 12.300 per 1 . 00 USD, lalu mengalami penguatan dimana pada tanggal 28 Oktober 2014 kurs transaksi USD terhadap IDR mencapai pada angka Rp. 11.500 per 1.00 USD. Menuju tanggal 21 Agustus 2015 kurs transaksi USD terhadap IDR mengalami pelemahan yang sangat tajam dimana sebelumnya nilai kurs transaksi sebesar Rp 11.500 per 1.00 USD lalu menjadi Rp 14.700 per 1.00 USD. Mendekati 13 Juni 2016 terjadi penguatan mata uang yang mencapai pada angka Rp 13.700 per 1.00 USD. Pada awal 3 April 2017 terjadi penguatan mata uang yang mencapai pada angka Rp. 13.300 per 1.00 USD. Dari data yang ditunjukkan, dapat diartikan bahwa ketika perusahaan melakukan transaksi valuta asing akan mengalami risiko terhadap eksposur valuta asing. Pada grafik dapat dilihat terdapat fluktuasi nilai tukar USD terhadap IDR yaitu dari tahun 2013 hingga 2017. Ketika IDR mengalami mengalami depresiasi atau ketika mata uang USD mengalami apresiasi, maka harga impor barang akan lebih mahal sehingga berdampak pada kenaikan harga yang juga akan mengalami peningkatan. Hal ini dapat menyebabkan kerugian bagi perusahaan yang melakukan transaksi internasional dengan perbedaaan valuta asing, karena ketika mata uang lokal mengalami depresiasi maka perusahaan harus mengeluarkan lebih banyak mata uang lokal untuk transaksi tersebut.

Aktivitas perdagangan internasional yang menggunakan valuta asing dalam transasksi ekspor maupun impor sehingga perusahaan memiliki risiko terkena dampak dari eksposur valuta asing. Kurs valuta asing yang berfluktuasi setiap 
tahunnya tentu akan mempengaruhi kegaiatn ekspor perusahaan, hal ini dapat dilihat pada Tabel 2 mengenai pergerakan kegiatan ekspor yang dilakukan oleh perusahaan manufaktur dari tahun 2013-2017.

Tabel 2.

Pertumbuhan Ekspor Menurut Sektor Usaha Tahun 2013 - 2017 (dalam Juta US\$)

\begin{tabular}{lrrrrr}
\hline No Sektor & 2013 & 2014 & \multicolumn{2}{c}{ Tahun } & \\
& $5.713,0$ & $5.770,6$ & $5.631,2$ & $5.465,8$ & $58.880,2$ \\
\hline 1. Pertanian & & & & & \\
$\begin{array}{l}\text { 2. Industri } \\
\text { pengolahan }\end{array}$ & $113.029,7$ & $117.329,6$ & $106.667,6$ & $108.373,3$ & $122.838,8$ \\
3. Pertambangan & $31.159,5$ & $22.850,3$ & $19.461,2$ & $18.171,5$ & $24.313,6$
\end{tabular}

Sumber: www.bps.go.id, 2017

Tabel 2 menggambarkan pertumbuhan ekspor menurut sektor usaha dari tahun 2013-2017. Pertumbuhan ekspor di dominasi oleh sektor manufaktur. Rata - rata kontribusi dari sektor manufaktur sebesar $81,72 \%$, sektor pertambangan sebesar $15,88 \%$ dan sektor pertanian sebesar 2,40\%. Tahun 2015 dapat dilihat bahwa perusahaan manufaktur mengalami penurunan ekspor hingga $-9,31 \%$, hal ini menandakan bahwa fluktuasi kurs valuta asing mempengaruhi tingkat ekspor perusahaan manufaktur.

Pesatnya pertumbuhan ekspor yang dilakukan oleh perusahaan manufaktur menyebabkan perusahaan cenderung terkena dampak dari risiko eksternal lebih banyak sehingga kemungkinan kerugian yang ditanggung oleh perusahaan lebih besar akibat dari perdagangan internasional yang dilakukan. Salah satu kerugian yang ditanggung oleh perusahaan dapat dilihat dari laporan keuangan perusahaan, dimana perusahaan akan menanggung beban yang lebih besar yang diakibatkan oleh adanya eksposur valuta asing. Eksposur valuta asing dapat dikatakan sebagai 
Ayuningtyas Putri Saraswati dan Ni Putu Santi Suryantini, Pengaruh Leverage, Firm..

suatu tingkat kepekaan terhadap perubahan riil aset, kewajiban atau pendapatan operasi yang dinyatakan dalam mata uang domestik terhadap perubahan kurs yang tidak dapat terantisipasi (Faisal, 2001:125). Perubahan omzet penjualan, penetapan harga produk, dan tingkat laba merupakan dampak dari adanya fluktuasi kurs valuta asing.

Risiko sangatlah penting untuk dikelola oleh perusahaan agar mampu untuk mempertahankan diri dari berbagai kemungkinan risiko yang timbul. Pengelolaan risiko dengan manajemen risiko dapat dilakukan dengan beberapa cara yaitu identifikasi risiko, evaluasi dan pengukuran risiko,dan pengelolaan risiko (Hanafi, 2009:10). Risiko fluktuasi kurs valuta asing akibat dari perdagangan internasional dapat dikelola menggunakan manajemen risiko dengan instrument derivatif (Mallin et al. 2001). Menurut Kurniawan (2018) menyatakan bahwa derivatif merupakan suatu kontrak perjanjian antara dua buah pihak untuk melakukan transaksi menjual atau membeli sejumlah aset tertentu (komoditas maupun finansial) dengan harga yang telah disepakati pada masa sekarang namun penggunaannya untuk dimasa yang akan datang. Terdapat empat teknik lindung nilai dengan menggunakan instrument derivative yaitu lindung nilai futures, lindung nilai forward, lindung nilai pasar uang, dan lindung nilai opsi mata uang (Madura, 2006:438).

Penggunaan kebijakan hedging pada negara - negara maju saat ini mengalami peningkatan setiap tahunnya. Penelitian empiris menemukan bahwa sebesar $60 \%$ perusahaan di Negara Inggris telah menggunakan derivatif dan di Negara Brazil sebesar 54\% perusahaan yang telah memanfaatkan produk dari 
derivatif (Schiozer dan Saito, 2009) namun, penelitian mengenai determinan kebijakan hedging masih sangat terbatas dan membutuhkan penelitian lebih luas terutama di negara berkembang. Candradewi (2018) melakukan penelitian mengenai penggunaan kebijakan hedging di Indonesia menemukan hanya sekitar $28,8 \%$ perusahaan yang menggunakan produk derivatif.

Indonesia merupakan salah satu negara yang termasuk dalam kategori negara berkembang, tentunya untuk melindungi aset perusahaan manufaktur dari fluktuasi kurs valuta asing perusahaan menggunakan kebijakan hedging agar mampu mengurangi risiko fluktuasi kurs valuta asing yang dihadapi (Fitrisari, 2011). Trend grafik aktivtias hedging yang dilakukan oleh perusahaan manufaktur dapat dilihat pada Gambar 2.

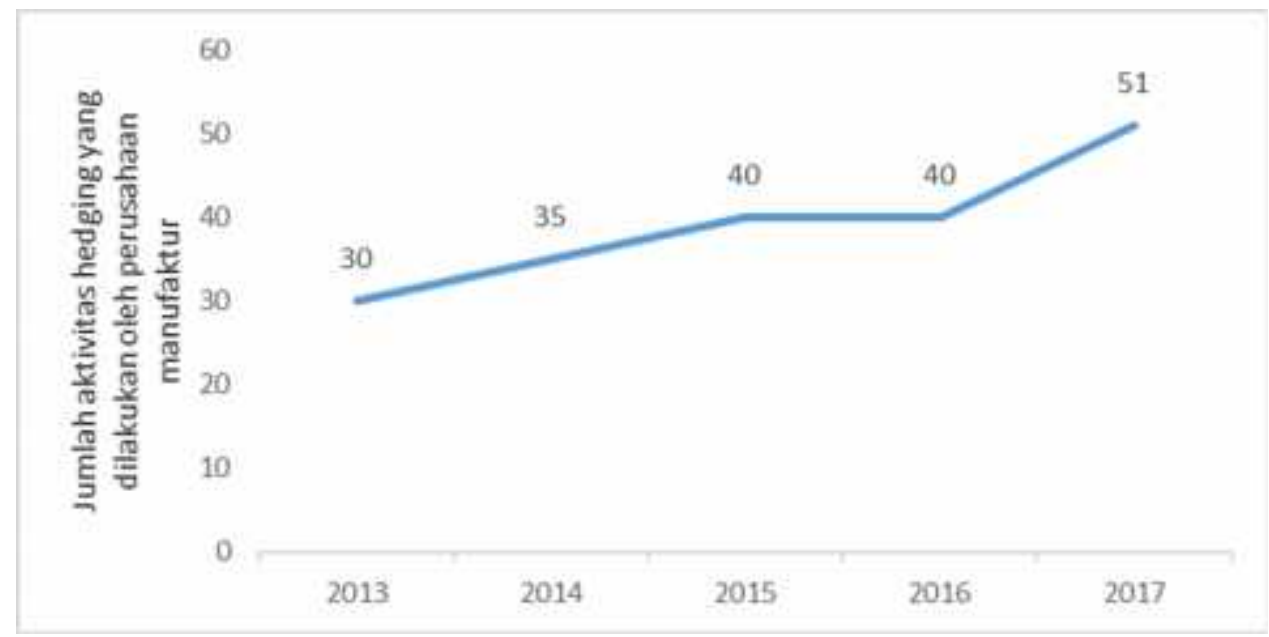

\section{Gambar 2 Trend Grafik Aktivitas Hedging yang dilakukan oleh Perusahaan Manufaktur Tahun 2013-2017}

Sumber: Laporan Tahunan Perusahaan manufaktur di Bursa Efek Indonesia (data diolah), 2018

Data pada Gambar 1 menunjukkan bahwa pada tahun 2013 terdapat 30 kali aktivitas hedging yang dilakukan oleh perusahaan manufaktur, kemudian meningkat hingga pada tahun 2017 terdapat 51 kali aktivitas hedging yang 
Ayuningtyas Putri Saraswati dan Ni Putu Santi Suryantini, Pengaruh Leverage, Firm..

dilakukan oleh perusahaan manufaktur. Menurut Tufano (1996) menyatakan bahwa penggunaan kebijakan hedging didalatarbelakangi oleh teori motivasi shareholder value maximization dimana pada teori ini membahas mengenai hipotesis yang berkaitan dengam kesulitan keuangan (financial distress). Widarjo (2009) menyatakan bahwa financial distress merupakan suatu tahap penurunan pada kondisi keuangan perusahaan sebelum perusahaan mengalami kebangkrutan atau likuidasi. Anggarini (2010) berpendapat bahwa terdapat beberapa faktor yang menyebabkan terjadinya financial distress pada perusahaan yaitu faktor ketidakcukupan modal, menderita kerugian akibat dari tingkat hutang yang tinggi dan besarnya beban bunga yang ditanggung oleh perusahaan.

Perusahaan multinasional dalam melakukan transaksi antar negara tentunya membutuhkan modal yang lebih besar. Perusahaan dapat melakukan pembiayaan melalui utang luar negeri. Penggunaan utang dapat membantu perusahaan dalam membiayai seluruh kegiatan perusahaan, namun disisi lain penggunaan dari utang luar negeri dalam jumlah besar dapat meningkatkan risiko perusahaan akibat dari fluktuasi kurs valuta asing. Agnes (2004) menyatakan bahwa leverage merupakan rasio utang yang menunjukkan kemampuan suatu perusahaan dalam memenuhi kewajiban finansial seandainya perusahaan tersebut dilikuidasai.

Ukuran perusahaan merupakan suatu pengelompokan besar kecilnya perusahaan yang dapat dilihat dari total aktiva dan total aset suatu perusahaan (Suwito, 2005). Ukuran perusahaan yang semakin besar berarti aktivitas perusahaan juga semakin luas sehingga risiko yang ditanggung perusahaan akan 
lebih besar, maka dari itu perusahaan cenderung menggunakan kebijakan hedging guna mengurangi risiko yang ditanggung oleh perusahaan.

Brigham et al. (2011:94) menyatakan bahwa keputusan yang dilakukan oleh perusahaan dapat memberikan hasil akhir yang disebut dengan profitabilitas. Profitabilitas menunjukkan efisiensi dan kinerja perusahaan serta berkaitan dengan tingkat pengembalian laba kepada investor. Shaari et al. (2013) menyatakan bahwa perusahaan yang memiliki potensi rendah terhadap kesulitan keuangan adalah perusahaan yang memiliki profitabilitas tinggi sehingga perusahaan cenderung tidak terlibat dalam aktivitas hedging.

Hasil penelitian terdahulu yang berkaitan dengan variabel leverage, firm size, dan profitabilitas terhadap keputusan hedging teridentifikasi adanya research gap antara variabel - variabel tersebut. Nguyen and Faff (2002) dan Candradewi (2018) menggunakan leverage menemukan hasil leverage berpengaruh positif signifikan terhadap keputusan hedging. Hal ini bertentangan dengan penelitian yang dilakukan oleh Triki (2005), Geczy et al. (1997), dan Jiwandhana (2016) menemukan hasil bahwa leverage berpengaruh positif signifikan terhadap keputusan hedging. Penelitian yang dilakukan oleh Guniarti (2014) dan Putro (2012) menemukan hasil bahwa ukuran perusahaan (firm size) berpengaruh positif dan signifikan terhadap keputusan hedging, sedangkan penelitian yang dilakukan oleh Ahmad (2012) dan Triki (2005) menemukan hasil bahwa ukuran perusahaan (firm size) berpengaruh negatif signifikan terhadap keputusan hedging. Penelitian yang dilakukan oleh Shaari et al. (2013) dan Clark (2010) menemukan hasil bahwa profitabilitas berpengaruh positif dan signifikan terhadap keputusan 
Ayuningtyas Putri Saraswati dan Ni Putu Santi Suryantini, Pengaruh Leverage, Firm..

hedging, sedangkan penelitian oleh Jiwandhana (2016), Jang (2011) dan Candradewi (2018) menemukan hasil bahwa profitabilitas berpengaruh negative signifikan terhadap keputusan hedging. Mengingat adanya hasil yang tidak konsisten antara yang satu dengan lainnya maka peneliti ingin menguji variabel sebelumnya dengan menggunakan sektor perusahaan manufaktur, pemilihan sektor perusahaan manufaktur didasari karena perusahaan manufaktur yang telah go-public dalam memenuhi kebutuhan bahan baku produksi tidak hanya didapatkan dari dalam negeri saja sehingga mendorong perusahaan melakukan transaksi internasional hal ini berarti bahwa risiko yang ditanggung perusahaan lebih besar.

Berdasarkan latar belakang masalah adapun tujuan dari penelitian ini diantaranya (1) Untuk mengetahui pengaruh leverage terhadap keputusan hedging, (2) Untuk mengetahui pengaruh firm size terhadap keputusan hedging, (3) Untuk mengetahui pengaruh profitabilitas terhadap keputusan hedging.

Manfaat teoritis penelitian ini diharapkan dapat memberikan bukti empiris terhadap manajemen keuangan internasional terkait pengaruh leverage, firm size dan profitabilitas terhadap keputusan hedging. Manfaat praktis dari penelitian ini diharapkan membantu perusahaan besar maupun kecil yang melakukan transaksi internasional untuk melakukan keputusan hedging guna meminimalisir risiko fluktuasi valuta asing.

Risiko berhubungan dengan sebuah ketidakpastian atau suatu proses yang sedang berlangsung atau kejadian dimasa yang akan datang (Hanafi, 2009:11). Risiko dapat dikelompokkan dalam dua tipe risiko yaitu risiko murni dan risiko 
spekulatif. Risiko murni merupakan risiko dimana kemungkinan kerugian ada namun kemungkinan keuntungan dari kejadian tersebut tidak ada, sedangkan risiko spekulatif dapat dikatakan sebagai suatu kondisi dimana masih terdapat keuntungan dibalik adanya risiko yang dihadapi oleh suatu perusahaan. Djohanputro (2008:12) mendefinisikan manajemen risiko sebagai suatu proses terstruktur dan sistematis dalam mengidentifikasi, mengukur, memetakan, mengembangkan alternatif penanganan risiko dan memonitor dan mengendalikan penanganan risiko.

Eksposur valuta asing merupakan suatu tingkat kepekaan perubahan pada nilai riil aset, pendapatan operasi, dan kewajiban yang dinyayatakan dalam mata uang domestic terhadap perubahan kurs yang tidak dapat diantisipasi (Faisal, 2001:87). Eksposur terhadap perubahan kurs valuta asing yang dihadapi oleh perusahaan multinasional dikelompokkan kedalam beberapa tipe yaiti eksposur transaksi, eksposur ekonomi, dan eksposur akuntansi.

Hedging merupakan tindakan membatasi risiko dan eksposur, eksposur tersebut timbul akibat kurs valuta asing yang mengalami fluktuasi kurs valuta asing (Madura, 2006:275). Hedging dikatakan sebagai salah satu fungsi ekonomi dari perdagangan berjangka yaitu transfer of risk dengan melakukan hedging tidak menutup kemungkinan perusahaan akan memperoleh keuntungan dengan melakukan investasi. Sunaryo (2009:23) menyatakan bahwa prinsip dari hedging adalah menutupi kerugian posisi aset awal dengan keuntungan dari posisi instrumen hedging. Derivatif merupakan kontrak perjanjian antara dua belah pihak untuk mentransaksikan aset baik dalam bentuk finansial maupun komoditi 
Ayuningtyas Putri Saraswati dan Ni Putu Santi Suryantini, Pengaruh Leverage, Firm..

ketika harga tetap pada tanggal yang akan terjadi dimasa depan ( Brigham et al. 2011:78). Hedging menggunakan instrumen derivatif dapat digunakan dengan melakukan future contract, forward contract, option contract, dan swap contract.

Hedging menggunakan instrumen keuangan derivatif dapat digunakan dengan melakukan future contract, forward contract, option contract, dan swap contract (Madura, 2006:278). Kontrak future merupakan pertukaran janji dagang untuk membeli atau menjual suatu aset di masa depan pada harga yang telah ditentukan terlebih dahulu (Madura, 2006:278). Kontrak forward merupakan kontrak antara dua belah pihak untuk membeli atau menjual suatu aset di masa depan pada harga yang telah disepakati sesuai dengan kebutuhan. Terdapat beberapa hal yang membedakan antara kontrak future dan kontrak forward yaitu (1) Nilai transaksi, lokasi pengiriman dan kualitas tidak di atur atau bebas sesuai dengan kesepakatan antara kedua belah pihak pada kontrak forward sedangkan pada kontrak future nilai transaksi telah ditentukan, (2) Tanggal pengiriman kontrak forward dapat disesuaikan, sedangkan pada kontrak future tanggal pengiriman dan waktu pengiriman telah di tetapkan oleh bursa atau pihak kliring. Option contract merupakan kontrak derivatif yang memberikan pilihan (hak) guna menjual atau membeli sesuatu sesuai dengan yang tertera di kontrak tersebut. Swap contract merupakan pengaturan antara kedua belah pihak untuk menukar suaru aliran arus kas berdasarkan suatu kontrak yang ditetapkan pada saat kontrak dibuat (Madura, 2006:301)

Leverage merupakan rasio yang menunjukkan kemampuan dari suatu perusahaan untuk memenuhi segala kewajiban finansial dari perusahaan 
seandainya perusahaan tersebut dilikuidasi (Agnes, 2004:40). Tujuan rasio ini adalah untuk mengukur bauran dana dalam neraca dan membuat perbandingan antara dana yang diberikan oleh pemilik (ekuitas) dan dana yang dipinjam atau hutang.

Ukuran perusahaan atau firm size merupakan besar kecilnya suatu perusahaan yang dapat dilihat dari besarnya nilai penjualan, nilai ekuitas dan nilai total aktiva. Ukuran perusahaan digunakan sebagai salah satu indikator untuk mengukur seberapa besar suatu perusahaan telah berkembang dilihat dari nilai total asset nya.

Profitabilitas merupakan hasil bersih dari berbagai kebijaksanaan dan keputusan yang diterapkan oleh sebuah perusahaan atau kemampuan perusahaan dalam menghasilkan laba dari penjualan produk atau jasa yang diproduksi perusahaan. Return on asset merupakan salah satu rasio yang digunakan untuk mengukur profitabilitas perusahaan. Hasil pengukuran dengan menggunakan ROA memperlihatkan hasil mengenai seberapa besar keuntungan yang didapat oleh perusahaan berdasarkan asset yang dimiliki.

Salah satu alternatif pendanaan yang dapat dilakukan perusahaan guna meningkatkan kinerja perusahaan yaitu dengan cara menggunakan hutang, namun tingginya tingkat hutang dapat berdampak buruk bagi perusahaan sehingga mendorong perusahaan untuk melakukan hedging guna melindungi perusahaan dari risiko tingkat hutang tersebut. Hasil penelitian yang dilakukan oleh Putro (2012) menunjukkan hasil bahwa variabel leverage yang diukur dengan menggunakan debt to equity ratio mendapatkan hasil positif signifikan, Guniarti 
Ayuningtyas Putri Saraswati dan Ni Putu Santi Suryantini, Pengaruh Leverage, Firm..

(2014) menemukan hasil positif pada variabel debt to equity ratio, dan Jiwandhana (2016) menemukan hasil debt to equity ratio berpengaruh positif signifikan terhadap keputusan hedging. Hasil penelitian sebelumnya menunjukkan adanya hubungan positif signifikan antara leverage terhadap keputusan hedging, berdasarkan hasil tersebut maka diperoleh hipotesis sebagai berikut:

$\mathrm{H}_{1} \quad$ : Leverage berpengaruh positif signifikan terhadap keputusan hedging

Perusahan besar cenderung mudah dalam menjalankan aktivitasnya dalam memperoleh pendanaan. Pendanaan tersebut diperoleh melalui transaksi valuta asing menyebabkan akan terkena dampak dari adanya fluktuasi kurs valuta asing, selain itu perusahaan besar cenderung melakukan ekspansi pasar ke negara negara lain sehingga risiko usaha yang ditanggung perusahaan akan semakin tinggi pula, maka perusahaan akan melakukan kebijakan hedging guna mengurangi risiko tersebut. Penelitian yang dilakukan oleh Nguyen and Faff (2002), Ameer (2010), Chen (2003) dan Putro (2012) melakukan penelitian menggunakan variabel ukuran perusahaan dengan menggunakan proksi $\operatorname{Ln}$ (Total Aset) mendapatkan hasil positif signifikan. Hasil penelitian sebelumnya menunjukkan hasil positif signifikan antara firm size terhadap keputusan hedging. Berdasarkan hasil penelitian sebelumnya, maka didapat hipotesis sebagai berikut : $\mathrm{H}_{2}$ : Firm size berpengaruh positif signifikan terhadap keputusan hedging.

Perusahaan dengan tingkat profitabilitas yang tinggi menandakan bahwa perusahaan kemungkinan besar terhindar dari financial distress (kesulitan keuangan) dengan demikian memiliki kecenderungan yang kurang dalam menerapkan kebijakan hedging. Hasil penelitian yang dilakukan oleh Jang (2011), 
Candradewi (2018) dan Kurniawan (2018) menemukan hasil bahwa variabel profitabilitas yang diukur dengan return on asset berpengaruh negative signifikan terhadap keputusan hedging. Berdasarkan hasil penelitian sebelumnya, maka didapat hipotesis sebagai berikut:

$\mathrm{H}_{3}$ : Profitabilitas berpengaruh negatif signifikan terhadap keputusan hedging.

\section{METODE PENELITIAN}

Penelitian ini merupakan penelitian dengan jenis asosiatif, dimana meneliti pengaruh sebab akibat. Penelitian ini menguji pengaruh leverage, firm size dan profitabilitas terhadap keputusan hedging. Ruang lingkup penelitian ini pada perusahaan manufaktur di Bursa Efek Indonesia periode 2013-2017. Obyek penelitian ini yaitu leverage, firm size, profitabilitas dan keputusan hedging. Alasan dipilihnya menggunakan perusahaan manufaktur dalam penelitian ini karena perusahaan manufaktur sering melakukan transaksi luar negeri terutama untuk mendapatkan bahan baku dan mesin untuk kegiatan operasional perusahaan sehingga hal ini meningkatkan risiko usaha yang akan ditanggung oleh perusahaan.

Variabel hedging dalam penelitian ini diukur dengan menggunakan variabel dummy, dimana perusahaan yang menggunakan hedging diberikan kode 1 sedangkan perusahaan yang tidak menggunakan hegding diberikan kode 0 .

Variabel leverage diukur dengan menggunakan debt to equity ratio, yang dirumuskan sebagai berikut (Horne dan Wachowicz, 2005):

$$
\text { DEK }=\frac{\text { Total Hutang }}{\text { Total Modal Sendiri }} \times 100 \%
$$


Ayuningtyas Putri Saraswati dan Ni Putu Santi Suryantini, Pengaruh Leverage, Firm..

Variabel firm size dalam penelitian ini diukur dengan melihat logaritma natural dari totoal aset yang dirumuskan sebagai berikut:

Firm Size $=\operatorname{Ln}($ Total Aset $)$

Variabel profitabilitas dalam penelitian ini diukur dengan menggunakan return on asset, yang dirumuskan sebagai berikut (Wiagustini,2010:84):

$$
\text { RUA }=\frac{\text { Laba Hersih Setelah Pajak }}{\text { Total Aset }} \times 100 \%
$$

Populasi dalam penelitian ini sebanyak 148 perusahaan manufaktur di Bursa Efek Indonesia. Sampel pada penelitian ini ditentukan dengan metode purposive sampling, adapun kriteria dalam penelitian ini yaitu (1) Perusahaan tersebut merupakan perusahaan manufaktur di bursa efek Indonesia (BEI) dan secara fundamental memiliki eksposur valuta asing yang timbul dari impor bahan baku, penjualan ekspor, aset dan kewajiban dalam valuta asing, atau memiliki anak perusahaan di luar negeri,(2) Perusahaan menyampaikan data secara lengkap (laporan keuangan dan laporan tahunan) selama periode penelitian tahun 20132017. Berdasarkan kriteria dalam penelitian didapatkan sampel sejumlah 107 perusahaan manufaktur yang masuk dalam kategori penelitian, sedangkan 41 perusahaan tidak dimasukkan kedalam sampel karena tidak menyampaikan laporan keuangan dan laporan tahunan secara lengkap.

Metode pengumpulan data pada penelitian ini menggunakan metode observasi non partisipan, dimana peneliti yang melakukan observasi sebagai pengumpul data tanpa harus ikut berpartisipasi pada fenomena yang diamati 
(Hariwijaya, 2007:58). Pengumpulan data dalam penelitian ini dilakukan dengan melihat jurnal, buku, skripsi dan tesis.

Jenis data yang digunakan dalam penelitian ini adalah data kualitatif dan kuantitatif, dimana data kualitatif diperoleh dari data yang berupa kalimat yaitu data perusahaan manufaktur sedangkan data kuantitatif merupakan data yang berbentuk angka yaitu data yang berupa nilai dari rasio DER, ROA, total aset dan nilai hedging. Sumber data yang digunakan dalam penelitian ini bersumber dari data sekunder yang berupa laporan keuangan dan laporan tahunan perusahaan manufaktur di Bursa Efek Indonesia periode 2013-2017.

Teknik analisis data yang digunakan dalam penelitian ini menggunakan teknik analisis regresi logistik. Adapun model umum regresi logistik yaitu sebagai berikut:

$$
\ln \frac{p}{1-p}=u+\beta 1 \times 1+\beta 2 \times 2+\beta 3 \times 3 .
$$

Keterangan:

$$
\begin{array}{ll}
L_{\pi l}=\frac{p}{1-p} & =\text { Aktivitas hedging dengan menggunakan instrumen derivatif } \\
L_{I l}=\frac{p}{1-p} & =1 \text { (terdapat aktivitas hedging) } \\
L_{\pi l}=\frac{p}{1-p} & =0 \text { (tidak terdapat aktivitas hedging) } \\
L_{I l} & =\text { Variabel dependen } \\
\mathrm{P} & =\text { Probabilitas } \\
\mathrm{u} & =\text { Konstanta regresi } \\
\beta 1 & =\text { Konstanta regresi variabel X1 } \\
\beta 2 & =\text { Konstanta regresi variabel X2 } \\
\beta 3 & =\text { Konstanta regresi variabel X3 } \\
\mathrm{X} 1 & =\text { Leverage } \\
\mathrm{X} 2 & =\text { Firm size } \\
\mathrm{X} 3 & =\text { Profitabilitas }
\end{array}
$$


Ayuningtyas Putri Saraswati dan Ni Putu Santi Suryantini, Pengaruh Leverage, Firm..

Tahap-tahap pengujian model regresi logistik menurut Ghozali (2013:73) yaitu sebagai berikut (1) Uji kelayakan model, (2) Menilai keseluruhan model, (3) Uji multikolinearitas, (4) Uji matriks klasifikasi, (5) Uji koefisien determinasi, (6) Uji t, (7) Uji koefisien regresi.

\section{HASIL DAN PEMBAHASAN}

Statistik deskriptif berhubungan dengan pengumpulan dan peringkat data yang menggambarkan karakteristik sampel. Analisis deskriptif pada penelitian ini menunjukkan nilai maximum, minimum, mean, dan standar deviasi dari masingmasing variabel bebas.

\section{Tabel 3.}

Hasil Uji Deskriptif Variabel Bebas

\begin{tabular}{lrrrrr}
\hline & $\mathrm{N}$ & \multicolumn{1}{l}{ Minimum } & Maximum & \multicolumn{1}{l}{ Mean } & \multicolumn{2}{c}{ Std. Deviation } \\
\hline DER & 535 & -10.41 & 14.38 & 1.2031 & 1.59941 \\
SIZE & 535 & 9.10 & 19.50 & 14.6648 & 1.68380 \\
ROA & 535 & -19.07 & 74.84 & 5.3259 & 9.18202 \\
\hline
\end{tabular}

Sumber : Data diolah, 2018

Data pada Tabel 3. dapat dilihat nilai minimum dari DER sebesar $-10,41$ terdapat pada PT Berlina Tbk tahun 2017 sedangkan nilai maksimum sebesar 14,38 yang terdapat pada PT. Intraco Penta Tbk tahun 2013. Rata - rata variabel DER sebesar 1,2031 dan standar deviasi sebesar 1,59941. Variabel firm size didapatkan nilai minimum sebesar 9,10 terdapat pada PT. Colorpak Indonesia Tbk tahum 2013 sedangkan nilai maksimum sebesar 19,50 yang terdapat pada PT. Astra International Tbk tahun 2017. Rata - rata dari variabel size sebesar 14,6648 dan standar deviasi sebesar 1,68380. Nilai minimum dari variabel ROA sebesar -19,07 yang terdapat pada PT. Tirta Mahakam Resouces Tbk tahun 2013 sedangkan nilai maksimum sebesar 74,84 yang terdapat pada PT. Duta Pertiwi 
Nusantara Tbk tahun 2013. Rata - rata variabel ROA yaitu sebesar 5,3259 dengan standar deviasi sebesar 9,18202. Sampel dengan variabel hedging (Y) dapat dilihat pada Tabel 4.

\section{Tabel 4.}

Hasil Uji Frekuensi Variabel Terikat

\begin{tabular}{lccccc}
\hline & & Frequency & Percent & Valid Percent & Cumulative Percent \\
\hline Valid & 0 & 339 & 63.4 & 63.4 & 63.4 \\
& 1 & 196 & 36.6 & 36.6 & 100.0 \\
& Total & 535 & 100.0 & 100.0 & \\
\hline
\end{tabular}

Sumber : Data diolah, 2018

Tabel 4 menunjukkan perusahaan manufaktur yang melakukan aktivitas hedging diberi kode 1 sedangkan perusahaan manufaktur yang tidak melakukan hedging diberi kode 0, dapat dilihat terdapat aktivitas hedging yang dilakukan oleh perusahaan manufaktur sebanyak 196 kali dan persentase sebesar 36,6\% sedangkan terdapat 339 kali aktivitas perusahaan dengan kategori tidak menggunakan hedging dan persentase sebesar $63,4 \%$.

Tabel 5.

Hosmer and Lemeshow Test

\begin{tabular}{cccc}
\hline Step & Chi-square & Df & Sig. \\
\hline 1 & 11.645 & 8 & .168 \\
\hline
\end{tabular}

Sumber: Data diolah, 2018

Hosmer and Lemeshow Test yang digunakan untuk menguji kelayakan model penelitian. Pada Tabel 5. didapatkan nilai statistik Hosmer and Lemeshow Test sebesar 11,645 dengan probabilitas signifikansi sebesar 0,168. Nilai siginifikansi menunjukkan angka sebesar 0,168 berarti bahwa model didalam penelitian ini dapat diterima karena cocok dengan data observasinya dan dapat menjelaskan hubungan variabel independen dan variabel dependennya. 
Tabel 6.

Iteration History ${ }^{\text {a.b.c.d }}$ Block Number $=0$

\begin{tabular}{cccc}
\hline & & & Coefficients \\
Iteration & & -2 Log likelihood & Constant \\
\hline Step 0 & 1 & 702.998 & -.535 \\
& 2 & 702.976 & -.548 \\
& 3 & 702.976 & -.548 \\
\hline
\end{tabular}

Sumber : Data diolah, 2018

Tabel 7.

Iteration History $^{\text {a,b,c,d }}$ Block Number $=1$

\begin{tabular}{ccccccc}
\hline \multicolumn{2}{c}{ Iteration } & & \multicolumn{5}{c}{ Coefficients } \\
\cline { 6 - 7 } Step 1 & 1 & 627.045 & -6.097 & .028 & .154 & .356 \\
& 2 & 624.054 & -7.327 & .035 & .198 & .428 \\
& 3 & 624.038 & -7.424 & .036 & .202 & .433 \\
& 4 & 624.038 & -7.424 & .036 & .202 & .434 \\
\hline
\end{tabular}

Sumber : Data diolah, 2018

Pada Tabel 6 dan Tabel 7 yang digunakan untuk menilai keseluruhan model dapat dilakukan dengan membandingkan nilai -2 Log Likehood (block number $=0$ ) dengan -2 Log Likehood (block number=1). Nilai pada -2 Log Likehood (block number $=0$ ) adalah sebesar 702,976 dan setelah dimasukkan tiga variabel independen nilai -2 Log Likehood pada akhir mengalami penurunan menjadi 624,038. Penurunan yang terjadi pada nilai -2 Log Likehood menunjukkan model regresi yang baik atau dengan kata lain model yang dihipotesiskan cocok dengan data.

Tabel 8.

Correlation Matrix

\begin{tabular}{lccccc}
\hline & & Constant & DER & SIZE & ROA \\
\hline Step 1 & Constant & 1.000 & -.089 & -.987 & -.987 \\
& DER & -.089 & 1.000 & -.020 & .007 \\
& SIZE & -.987 & -.020 & 1.000 & -.020 \\
& ROA & -.099 & .263 & .007 & 1.000 \\
\hline
\end{tabular}

Sumber : Data diolah, 2018 
Hasil Tabel 8 menunjukkan tidak terdapat nilai koefisien antar variabel yang nilainya lebih besar dari 0,8 sehingga dapat disimpulkan bahwa tidak terdapat gejala multikolinearitas yang serius antar variabel.

Tabel 9.

Classification Table ${ }^{\mathrm{a}}$

\begin{tabular}{cccccc}
\hline & & & Hedge & Predicted & \\
\multicolumn{2}{c}{ Observed } & & 0 & 1 & Percentage Correct \\
\hline Hedge & 0 & 292 & 47 & 86.1 \\
& 1 & 116 & 80 & 40.8 \\
\multicolumn{2}{c}{ Overall Percentage } & & & 69.5 \\
\hline
\end{tabular}

Sumber : Data diolah, 2018

Tabel 9. baris pertama terlihat jumlah sampel yang tidak melakukan aktivitas hedging sebanyak 339 sampel (292+47). Model regresi dalam penelitian ini menunjukkan adanya pengurangan sejumlah sampel 47 perusahaan sehingga total sampel yang tidak melakukan aktivitas hedging adalah sebanyak 292 perusahaan. Ketepatan klasifikasi pada model ini untuk memprediksi kemungkinan perusahaan tidak melakukan aktivitas hedging sebesar 86,1\%. Baris kedua menunjukkan bahwa terdapat 196 sampel (116+80) yang melakukan aktivitas hedging. Model ini memprediksi adanya pengurangan sejumlah 116 sampel perusahaan sehingga total sampel perusahaan yang diperdiksi melakukan hedging sebanyak 80 sampel perusahaan. Ketepatan klasifikasi pada model ini untuk memprediksi kemungkinan perusahaan melakukan hedging sebesar 40,8\%. Secara keseluruhan, ketepatan klasifikasi pada model regresi ini adalah adalah $69,5 \%$.

Tabel 10. menunjukkan hasil uji koefisien determinasi dengan melihat nilai Nagelkerke $R$ Square sebesar 0,188 . Nilai tersebut berarti bahwa variasi dari 
Ayuningtyas Putri Saraswati dan Ni Putu Santi Suryantini, Pengaruh Leverage, Firm..

variabel DER, Size dan ROA (variabel independen) mampu menjelaskan variasi dari hedging (variabel dependen) sebesar 18,8\% sedangkan 81,2\% dijelaskan oleh variasi variabel lain yang tidak dimasukkan dalam model persamaan regresi.

Tabel 10.

Model Summary

\begin{tabular}{cccc}
\hline Step & -2 Log likelihood & $\begin{array}{l}\text { Cox \& Snell R } \\
\text { Square }\end{array}$ & $\begin{array}{l}\text { Nagelkerke R } \\
\text { Square }\end{array}$ \\
\hline 1 & $624.038^{\mathrm{a}}$ & .137 & .188 \\
\hline
\end{tabular}

Sumber : Data diolah, 2018

Tabel 11.

Variables in the Equation

\begin{tabular}{|c|c|c|c|c|c|c|}
\hline & & B & S.E. & Wald & Df & Sig. \\
\hline \multirow{4}{*}{ Step $1^{\mathrm{a}}$} & DER & .202 & .066 & 9.481 & 1 & .002 \\
\hline & SIZE & .434 & .062 & 48.304 & 1 & .000 \\
\hline & ROA & .036 & .011 & 9.963 & 1 & .002 \\
\hline & Constant & -7.424 & .942 & 62.063 & 1 & .000 \\
\hline
\end{tabular}

Uji parsial (Uji t) dapat dilihat pada Tabel 11. untuk menghitung uji t dilakukan dengan membandingkan $t_{\text {hitung }}$ dengan $t_{\text {tabel. }}$ Taraf nyata $5 \%: 2=2,5 \%$ (uji dua sisi) dengan derajat kebebasan (df) $n-k=535-3=532$. Dengan pengujian dua sisi (signifikansi $=1,960)$.

Variabel DER dengan nilai $t_{\text {hitung }}(3,154)>t_{\text {tabel }}(1,960)$. Dengan melihat signifikansi pada SPSS didapat nilai signifikansi $0,002<0,05$ maka dari itu variabel DER berpengaruh signifikan terhadap keputusan hedging.

Variabel Size dengan nilai $t_{\text {hitung }}(6,950)>t_{\text {tabel }}(1,960)$. Dengan melihat signifikansi pada SPSS didapat nilai signifikansi $0,000<0,05$ maka dari itu variabel Size berpengaruh signifikan terhadap keputusan hedging. 
Variabel ROA dengan nilai $t_{\text {hitung }}(3,156)>t_{\text {tabel }}(1,960)$. Dengan melihat signifikansi pada SPSS didapat nilai signifikansi $(0,002)<(0,05)$ maka dari itu variabel ROA berpengaruh signifikan terhadap terhadap keputusan hedging.

Tabel 12.

Variables in the Equation

\begin{tabular}{|c|c|c|c|c|c|c|}
\hline & & B & S.E. & Wald & Df & Sig. \\
\hline \multirow[t]{4}{*}{ Step $1^{a}$} & DER & .202 & .066 & 9.481 & 1 & .002 \\
\hline & SIZE & .434 & .062 & 48.304 & 1 & .000 \\
\hline & ROA & .036 & .011 & 9.963 & 1 & .002 \\
\hline & Constant & -7.424 & .942 & 62.063 & 1 & .000 \\
\hline
\end{tabular}

Model regresi yang terbentuk berdasarkan nilai estimasi parameter dalam Variable in The Equation adalah sebagai berikut:

$$
\mathrm{Ln} \frac{P}{1-P}=-1,424+0,202 \mathrm{DER}+0,434 \mathrm{SIZE}+0,036 \mathrm{RUA}
$$

Variabel debt to equity ratio (DER) yang merupakan proksi dari leverage menunjukkan nilai koefisien regresi sebesar 0,202 dengan pergerakan nilai probabilitas variabel sebesar 0,002 yang lebih kecil dari tingkat signifikansi 0,05 (5\%) sehingga $\mathrm{H}_{1}$ diterima dan $\mathrm{H}_{0}$ ditolak, maka variabel DER memiliki pengaruh yang positif dan signifikan terhadap keputusan hedging . Hasil penelitian yang bernilai positif dan signifikan berarti bahwa perusahaan dalam struktur modalnya ketika memiliki modal lebih besar yang dibiayai oleh hutang dibandingkan dengan modal sendiri tentunya dapat meningkatkan risiko yang ditanggun oleh perusahaan. Semakin tinggi hutang yang dimiliki perusahaan mengharuskan perusahaan berhati- hati dalam menjalankan kegiatan operasi perusahaan terutama saat melakukan transaksi internasional agar terhindar dari fluktuasi kurs valuta 
Ayuningtyas Putri Saraswati dan Ni Putu Santi Suryantini, Pengaruh Leverage, Firm..

asing, maka dari itu perusahaan cenderung menggunakan hedging guna meminimalisir risiko yang timbul akibat dari fluktuasi kurs yang berdampak pada perusahaan. Hasil pengujian ini sesuai dengan temuan dari penelitian Megawati (2016), Nguyen and Faff (2002) dan Ariani (2017) menemukan hasil bahwa leverage yang diukur dengan menggunakan DER berpengaruh positif signifikan terhadap keputusan hedging pada perusahaan sektor pertambangan di Indonesia.

Variabel Firm Size menunjukkan nilai koefisien regresi sebesar 0,434 dengan pergerakan nilai probabilitas variabel sebesar 0,000 yang lebih kecil dari tingkat signifikansi 0,05 (5\%), maka variabel firm size memiliki pengaruh yang positif signifikan terhadap keputusan hedging pada perusahaan manufaktur. Hasil penelitian yang bernilai positif dan signifikan hal ini berarti bahwa semakin besar ukuran suatu perusahaan akan cenderung menggunakan hedging guna melindungi aset yang dimilikinya. Ukuran perusahaan yang besar tentunya memiliki aktivitas operasional perusahaan yang luas hingga merambat ke dunia internasional. Berbagai transaksi internasional yang dilakukan seperti ekspor, impor, pembelian bahan baku guna memperluas pangsa pasar dan meningkatkan produksi perusahaan tentunya akan menimbulkan risiko fluktuasi kurs valuta asing yang ditanggung perusahaan akibat dari transaksi internasional yang dilakukan sehingga akan meningkatkan perusahaan dalam menggunakan hedging guna meminimalisir risiko yang timbul akibat adanya fluktuasi kurs valuta asing. Hasil pengujian ini sesuai dengan penelitian yang dilakukan oleh Megawati (2016), Nguyen and Faff (2002), Guniarti (2014) serta Raghavendra (2014) yang 
melakukan penelitian tentang size dan menemukan hasil bahwa size berpengaruh positif dan signifikan terhadap keputusan hegding.

Variabel Profitabilitas menunjukkan nilai koefisien regresi sebesar 0,036 dengan pergerakan nilai probabilitias variabel sebesar 0,002 yang lebih kecil dari tingkat signifikansi $0,05(5 \%)$, sehingga $\mathrm{H}_{1}$ ditolak dan $\mathrm{H}_{0}$ diterima, maka variabel profitabilitas menunjukkan nilai positif signifikan terhadap keputusan hedging. Profitabilitas menunjukkan tingkat efektivitas kinerja perusahaan dalam memperoleh laba dengan menggunakan aktiva yang dimiliki oleh perusahaan. Perusahaan yang memiliki tingkat profitabilitas yang tinggi cenderung lebih cepat dalam melakukan ekspansi bisnis atau perluasan pangsa pasar. Pasar internasional yang bersifat dinamis menyebabkan perubahan yang terjadi didalamnya dapat menyebabkan kerugian bagi perusahaan yang melakukan transaksi dalam jumlah yang besar sehingga dapat meningkatkan risiko yang akan ditanggung oleh perusahaan. Tingginya risiko yang akan dialami oleh perusahaan ketika melakukan perluasan pangsa pasar akan mendorong perusahaan dalam melakukan hegding dengan menggunakan instrumen derivatif. Hasil pengujian ini sesuai dengan penelitian yang dilakukan oleh Rizal (2017), Jiwandhana (2016), Megawati (2016), Shaari et al. (2013) serta Clark (2010) menggunakan ROA sebagai alat ukur dari Profitabilitas juga menemukan hasil bahwa ROA berpengaruh positif signifikan terhadap keputusan hedging.

\section{SIMPULAN DAN SARAN}

Berdasarkan hasil analisis data serta pembahasan pada masing - masing variabel yang telah dipaparkan maka dapat ditarik kesimpulan dari hasil pengujian 
Ayuningtyas Putri Saraswati dan Ni Putu Santi Suryantini, Pengaruh Leverage, Firm..

variabel leverage, firm size, dan profitabilitas terhadap keputusan hedging pada perusahaan manufaktur yang terdapat di Bursa Efek Indonesia periode 2013 2017 yaitu:

Hasil penelitian menunjukan bahwa leverage memiliki pengaruh positif dan signifikan terhadap keputusan hedging dengan menggunakan instrumen derivatif. Hal ini berarti semakin tinggi tingkat leverage maka akan semakin tinggi pula perusahaan menggunakan hedging guna melindungi perusahaan dari risiko kurs valuta asing.

Hasil penelitian menunjukkan bahwa firm size memiliki pengaruh positif dan signifikan terhadap keputusan hedging dengan menggunakan instrumen derivatif. Hal ini berarti semakin tinggi tingkat firm size maka perusahaan akan cenderung menggunakan hedging guna melindungi asset perusahaan.

Hasil penelitian menunjukkan bahwa profitabilitas memiliki pengaruh positif dan signifikan terhadap keputusan hedging dengan menggunakan instrumen derivatif. Hal ini berarti semakin tinggi tingkat profitabilitas suatu perusahaan maka perusahaan akan cenderung menggunakan hedging.

Berdasarkan kesimpulan tersebut maka saran yang dapat disampaikan adalah Bagi perusahaan manufaktur dengan ukuran perusahaan kecil, sedang maupun besar dan memiliki tingkat profitabilitas yang rendah diharapkan menggunakan kebijakan hedging ketika melakukan transaksi internasional agar perusahaan dapat menghindari risiko - risiko seperti fluktuasi kurs valuta asing. Bagi perusahaan yang memiliki tingkat hutang yang tinggi diharapkan menggunakan kebijakan hedging ketika melakukan transaksi internasional agar 
perusahaan mampu mengurangi beban hutang yang dimiliki dari risiko fluktuasi kurs valuta asing. Peneliti selanjutnya disarankan dapat meneliti lebih lanjut mengenai faktor - faktor yang mempengaruhi keputusan hedging selaian dari variabel dalam penelitian ini seperti likuiditas, kebijakan deviden, dan market to book value, dan proporsi komisaris dengan menggunakan sektor yang berbeda seperti sektor food and beverage, otomotif, dan pertambangan, selain itu diharapkan meneliti financial distress hypothesis di Indonesia dengan hedging sebagai perantara dari financial distress.

\section{REFERENSI}

Anggarini, Tifani Vota. (2010). Pengaruh Karakteristik Komite Audit Terhadap Financial Distress (Studi Empiris Pada Perusahaan Yang Terdaftar Di Bursa Efek Indonesia). Diponogoro Journal Of Accounting, 3(2), 1-12

Bartram Shonke M. (2008). Ehat Lies Beneath: Foreign Exchange Rate Exposure, Hedging And Cash Flow. Journal Of Banking \& Finance, 8(32), 1508-1521

Brigham, Eugene F. (2011). Dasar-dasar Manajemen Keuangan, Edisi Sepuluh. Jakarta: Salemba Empat

Candradewi, Made Reina Dan Henny Rahyuda. (2018). Variabel -Variabel Penentu Pengguna Derivatif Perusahaan Non- Keuangan Di Bursa Efek Indonesia. Jurnal Manajemen, Strategi Bisnis Dan Kewirausahaan, 12(1), $1-86$

Clark, E., \& Mefteh, S. (2010). Foreign Currency Derivatives Use, Firm Value and the Effect of the Exposure Profile: Evidence from France. International Journal of Business, 15(2), 215-344

Dewi, Melawati Puspita Dan Indah Susantun. (2018). Analisis Ekspor Batu Bara Indonesia. Jurnal Akuntansi dan Audit Indonesia, 22(1), 1-19

Djohanputro, Brahmantyo. (2008). Manajemen Keuangan Korporat. Jakarta: Penerbit PPM

Faisal, M. (2001). Manajemen Keuangan Internasional. Jakarta: Salemba Empat

Fitriasari, Fika. (2011). Value Drivers Terhadap Nilai Pemegang Saham Perusahaan Yang Hedging Derivatif Valuta Asing. Jurnal Manajemen 
Bisnis, 1(1), 89-102

Fitri, Ida Ayu Diah Dan Ida Bagus Pt Purbadharmaja. (2015). Pengaruh Kurs Dollar Amerika, Jumlah Produksi dan Luas Lahan Pada Volume Ekspor Lada Indonesia. E- Journal Ekonomi Pembangunan Unud, 4(5), 348-667

Guniarti, Fay. (2014). Faktor-Faktor yang Mempengaruhi Aktivitas Hedging dengan Instrumen Derivatif Valuta Asing. Jurnal Dinamika Manajemen. $5(1), 64-79$

Hanafi, Mamduh. (2009). Manajemen Risiko, Edisi Ketiga. Yogyakarta: Unit Penerbit Dan Percetakan Sekolah Tinggi Ilmu Manajemen Ykpn

Jang, S., \& Park, K. (2011). Inter-relationship between firm growth and profitability. International Journal of Hospitality Management, 30(2), 10271035

Jiwandhana, Rm Satwika Putra Dan Nyoman Triaryati. (2016). Pengaruh Leverage Dan Profitabilitas Terhadap Keputusan Hedging Perusahaan Manufaktur Indonesia. E-Journal Manajemen Unud, 5(1), 31-58

Krisdian, Ni Putu Candra Dan Ida Bagus Badjra. (2017). Pengaruh Ukuran Perusahaan, Tingkat Hutang, Dan Kesulitan Keuangan Terhadap Keputusan Hedging Pada Perusahaan Manufaktur Indonesia. E-Journal Manajemen Unud, 6(3), 1452-1477

Kurniawan, Dimas Prasetyo Dan Nadia Asandimitra. (2018). Analisis Faktor Yang Mempengaruhi Penggunaan Instrumen Derivatif Sebagai Pengambilan Keputusan Hedging Pada Perusahaan Sektor Keuangan Yang Terdaftar Di Bei Periode 2011-2015, Jurnal Ilmu Manajemen. 6(1), 1-11

Madura, Jeff. (2006). Keuangan Perusahaan Internasional, Edisi Kedelapan. Jakarta: Salemba Empat

Mallin, C., Ow-Yong, K., dan Reynolds.M. (2001). Derivatives Usage in U.K Non- Financial Listed Companies. European Journal of Finance, 7(3), 6391

Nguyen Hoa, Faff Robert. (2002). On The Determinants of Derivative Usage by Australian Companies, Australian of Journal Management, 27(1), 1-24

Rodoni, Ahmad Dan Herni Ali. (2010). Manajemen Keuangan, Edisi Pertama. Jakarta: Mitra Wacana Media

Shaari, Noor Azizah, Nurfadhilah Abu Hasan, Yamuna Rani Palanimally Dan Rames Kumar Moona Haji Mohamed. (2013). The Determinants Of Derivative Usage: A Study On Mallaysian Firms. Interdisciplinary Journal 
Of Contemporary Research In Business, 5(2), 300-316

Schiozer, R. F. dan R. Saito. (2009). The Determinants of Currency Risk Management in Latin American non-financial firms. Emerging Markets Finance and Trade, 45(1), 49-71

Sunaryo, T. (2009). Manajemen Risiko Finansial. Salemba Empat: Jakarta

Suwito, Edy dan Arlen Herawati. (2005). Analisis Pengaruh Karakteristik Perusahaan terhadap Tindakan Perataan Laba yang Dilakukan oleh Perusahaan yang terdaftar di Bursa Efek Jakarta. SNA VIII, 4(7), 65-78

Triki, Thouraya. (2005). Research on Corporate Hedging Theories:A Critical Review of the Evidence to Date. Departement of Finance and Canada Research Chair Risk Management HEC Montreal, 45(2), 987-1007

Tufano, P. (1996). Who Manages Risk? Aneempirical Examination Of Risk Management Practices In The Gold-Mining Industry. Journal Of Finance, 51(4), 1097-1137

Widarjo, Wahyu dan Setiawan. (2009). Pengaruh Rasio Keuangan terhadap Kondisi Financial Distress Perusahaan Otomotif. Jurnal Bisnis dan Akuntansi, 11(2), 107-119 